\title{
Integral inequalities via several kinds of convexity
}

\section{EMIN ÖZDEMIR, ERHAN SET and MOHAMmAD AlOMARI}

\section{ABSTRACT.}

Several integral inequalities via some kinds of convexity are obtained.

\author{
ATATÜRK UNIVERSITY \\ K. K. EDUCATION FACULTY \\ DEPARTMENT OF MATHEMATICS \\ 25240, CAMPUS, ERZURUM, TURKEY \\ E-mail address: emos@atauni.edu.tr, mozdemirr@yahoo.com \\ DEPARTMENT OF MATHEMATICS \\ FACULTY OF SCIENCE AND ARTS \\ DÜZCE UNIVERSITY \\ DÜZCE, TURKEY \\ E-mail address: erhanset@yahoo.com
}

DepartMENT OF MATHEMATICS

FACULTY OF SCIENCE

JERASH UNIVERSITY, 26150 JERASH, JORDAN

E-mail address: mwomath@gmail.com. 